\title{
Effect of hormone treatment on spontaneous and radiation-induced chromosomal breakage in normal and dwarf mice
}

\author{
Paul P.W. van Buul ${ }^{a, c}$ and Sylvia van Buul-Offers ${ }^{b}$ \\ ${ }^{a}$ Department of Radiation Genetics and Chemical Mutagenesis, State University of Leiden, Sylvius \\ Laboratories, Wassenaarseweg 72, 2333 AL Leiden (The Netherlands); ${ }^{b}$ Department of Pediatrics, \\ University of Utrecht, Wilhelmina Children's Hospital, Nieuwe Gracht 137, 3512 LK Utrecht (The \\ Netherlands); and 'J.A. Cohen Institute, Interuniversity Institute for Radiopathology and Radiation \\ Protection, 2333 AD Leiden (The Netherlands)
}

(Received 15 April 1982)

(Accepted 18 May 1982)

\section{Summary}

Treatment of dwarf mice with growth hormone, insulin and testosterone had no effect on the spontaneous frequencies of micronuclei (MN) in bone-marrow cells, whereas thyroxine decreased these frequencies. The induction of $\mathrm{MN}$ by $\mathrm{X}$-rays and mitomycin $\mathrm{C}$ was significantly lower in dwarf mice than in normal mice. Treatment with thyroxine plus growth hormone restored normal radiosensitivity in dwarfs.

Gonadotropic hormones and oral contraceptives are frequently used for therapeutic or experimental induction, respectively, of inhibition of ovulation in human and other mammals. During the last few years, various aspects of mutagenesis of these substances have been studied (Elbling, 1975; Bishun et al., 1976, for review).

The recent introduction of many other hormones taken continuously for a relatively long period of time for therapeutic use by patients suffering from endocrine disorders, has raised the problem of possible mutagenic effects of such therapies. However, only limited data are available on mutagenic effects of hormones influencing cell multiplication, such as growth hormone $(\mathrm{GH})$ and thyroxine (DucaMarinescu and Negoescu, 1973; Duca-Marinescu and Simionescu, 1973; Nilsson et al., 1975). The dwarf mouse, discovered in 1929 by Snell, shows many similarities with panhypopituitarism in man. As in man, the severe growth retardation, which becomes apparent 2 weeks after birth, is partially restored by hormonal treatment (van Buul-Offers and van den Brande, 1978, 1979). The similarity of this animal model with the clinical situation in humans prompted us to study the frequency of 
chromosomal aberrations in Snell dwarf mice after treatment with GH, thyroxine, testosterone and insulin, using the bone-marrow micronucleus test.

It is now well established that types and frequencies of radiation-induced chromosomal aberrations are strongly cell cycle-dependent (Evans, 1962; Kihlman, 1977). Since there are indications that $\mathrm{GH}$ and thyroxine have an effect on the cell cycle of bone-marrow cells (Bardik, 1969; Romanov et al., 1969; Romanov and Kasavina, 1970; and Judin and Antipenko, 1972), it seemed of interest to study the induction of chromosomal aberrations by $\mathrm{X}$-rays in the above-mentioned dwarf mice before and after hormone treatment.

\section{Materials and methods}

\section{Animals}

Dwarf mice $(\mathrm{dw} / \mathrm{dw})$ and phenotypically normal Snell mice $(\mathrm{dw} /+;+/+)$ were bred by mating heterozygotes at the Central Animal Center, Medical School, Rotterdam. They were kept under standardized laboratory conditions (temperature $24^{\circ} \mathrm{C}, 40 \%$ humidity, 12-h day-night rhythm), as described elsewhere (van BuulOffers and van den Brande, 1978).

Swiss random-bred male mice $(\mathrm{Cpb}(\mathrm{SE}) \mathrm{S})$ were obtained from the Central Institute for the Breeding of Laboratory Animals, Zeist, The Netherlands, and kept under normal laboratory conditions.

\section{Hormones}

Human growth hormone (hGH) ( $2 \mathrm{U} / \mathrm{mg}$ ) was a gift from AB Kabi (Stockholm). Porcine growth hormone $(\mathrm{pGH})(1 \mathrm{U} / \mathrm{mg})$ was obtained from Koch-Light, porcine insulin (Actrapid) from Novo, L-thyroxine $\left(\mathrm{T}_{4}\right)$ and testosterone from Sigma.

Solutions of the hormone, except testosterone, were prepared in sterile $0.9 \%$ $\mathrm{NaCl}, \mathrm{pH} 7.4$, stored at $-20^{\circ} \mathrm{C}$ and used for 3-4 weeks. $\mathrm{pGH}$ and $\mathrm{T}_{4}$ were first dissolved under alkaline conditions $(0.1 \mathrm{NaOH})$ in saline; the $\mathrm{pH}$ was adjusted to 8.0 with $\mathrm{HCl}$.

Testosterone was dissolved in a few drops of $96 \%$ ethanol and suspended in sterile arachis oil (Lansberg, Rotterdam).

\section{Experimental design}

To study the possible mutagenic effects of hormone treatment in vivo, male and female dwarf mice aged 6-8 weeks were treated with $\mathrm{pGH}, \mathrm{hGH}, \mathrm{T}_{4}$, insulin and testosterone. The animals were injected subcutaneously in the neck during 5 days a week at around $10.00 \mathrm{~h}$ with $0.1 \mathrm{ml}$ hormone solution at different dosages, for various lengths of time (Table 1). Injections with insulin were given 3 times a day. Control animals received $0.1 \mathrm{ml}$ saline, and in the testosterone experiment $0.1 \mathrm{ml}$ oil. The animals were killed by decapitation under ether anaesthesia, $2 \mathrm{~h}$ after the last injection. The femurs were removed and bone-marrow smears made by following the standard technique of Lederbur and Schmid (1973). For each femur, 1000 polychromatic erythrocytes were analyzed for the presence of micronuclei (MN) indicative 
for chromosomal breakage. The radiation studies were performed with a Siemens Stabilipan X-ray machine operating at $240 \mathrm{kV}$ and $15 \mathrm{~mA}$ resulting in an HVL of 3.2 $\mathrm{mm} \mathrm{Cu}$ and an absorbed exposure rate of $60 \mathrm{rad} / \mathrm{min}$ at a distance of $40 \mathrm{~cm}$ from the source. Different doses and sampling times were used to study the induction of $\mathrm{MN}$ in polychromatic erythrocytes of dwarf mice. In one experiment, mitomycin $\mathrm{C}$ was used as a mutagenic agent. In all experiments 2 femurs per animal and 1000 polychromatic erythrocytes per femur were analyzed. Significance of differences was calculated with the Student $t$ test.

\section{Results}

\section{Hormone-treated dwarf mice}

Treatment of dwarf mice with hGH, pGH and thyroxine at the dosages used in Table 1 stimulated growth of these animals, although normal values were not reached. Insulin at the doses tested had only a minimal effect on body growth, whereas testosterone had no effect at all (van Buul-Offers and van den Brande, 1978, 1979).

The normally hypothyroid dwarf mice become euthyroid by treatment with $0.1 \mu \mathrm{g}$ thyroxine, whereas $1 \mu \mathrm{g}$ thyroxine induced severe hyperthyroidism (van Buul-Offers and van den Brande, 1979).

The results of bone-marrow-smear analysis after hormone treatment of dwarf mice, are summarized in Table 1 . When no significant differences, for different hormone concentrations, were found, the data were pooled. In normal as well as dwarf mice the spontaneous frequency of $\mathrm{MN}$ in males was significantly higher than in females, a difference that seemed to disappear at older age in the normal Snell strain. In Swiss mice this sex difference did not occur. None of the hormone treatments used induced an increase in the frequencies of $\mathrm{MN}$ present in polychromatic erythrocytes. In dwarf mice treated with pGH alone and hGH, the observed sex difference was maintained, in contrast, a slight but significant decrease was seen in the males after treatment with insulin, testosterone and $1 \mu \mathrm{g}$ thyroxine alone or in combination with hGH. Owing to this effect, sex differences are no longer apparent in these groups, except for the testosterone-treated animals.

\section{Mutagen treatments}

Radiation experiments with the two mouse strains and 300 rad X-rays are presented in Table 2 as induced MN per 1000 cells. Since, with the experimental group size used, no significant differences were observed in response to irradiation, or to mitomycin $\mathrm{C}$, between females and males, data for both sexes were pooled. No differences in the frequencies of induced $\mathrm{MN}$ in polychromatic erythrocytes of Swiss random-bred and normal Snell mice were present, with a time interval of $18 \mathrm{~h}$ between irradiation and sampling. In dwarf mice, lower values were obtained. The low induction of MN in dwarf mice was consistent at sampling times of 18 and $24 \mathrm{~h}$. In both strains of mouse, the frequencies obtained were lower at $24 \mathrm{~h}$ sampling time than at $18 \mathrm{~h}$. Because the developmental age of dwarf mice is grossly comparable 
TABLE 1

FREQUENCIES OF MN IN BONE-MARROW CELLS OF CONTROLS AND HORMONETREATED DWARF MICE

\begin{tabular}{|c|c|c|c|c|c|}
\hline \multirow[t]{2}{*}{ Age (weeks) } & \multirow{2}{*}{\multicolumn{2}{|c|}{ Controls }} & \multicolumn{2}{|c|}{$\begin{array}{l}\text { Number of MN per } 1000 \text { poly- } \\
\text { chromatic erythrocytes } \pm \text { S.E.M. }\end{array}$} & \multirow{2}{*}{$\begin{array}{l}\text { Levels of } \\
\text { signifi- } \\
\text { cance. } \\
P<0.05 \\
\text { between } \\
\text { the sexes }\end{array}$} \\
\hline & & & Female & Male & \\
\hline $9-13$ & \multicolumn{2}{|c|}{$+/+($ Snell $)$} & \multirow[t]{2}{*}{$1.2 \pm 0.4(10)^{a}$} & $6.1=0.6(15)$ & $s$ \\
\hline 23 & & & & $2.8 \pm 0.8$ & \\
\hline $10-13$ & \multicolumn{2}{|c|}{$\mathrm{dw} / \mathrm{dw}$ (Snell) } & $3.9 \pm 1.3(12)$ & $7.9 \pm 1.3(17)$ & $\mathrm{s}$ \\
\hline $18-23$ & & & $1.9 \pm 0.4(12)$ & $7.6 \pm 0.9(15)$ & s \\
\hline $10-20$ & \multicolumn{2}{|c|}{$+/+$ (Swiss) } & $4.2 \pm 1.1(29)$ & $4.9 \pm 0.7(20)$ & ns \\
\hline \multicolumn{2}{|c|}{ Hormone treatment } & $\begin{array}{l}\mathrm{dw} / \mathrm{dw} \\
\text { (Snell) } \\
\text { weeks of } \\
\text { treatment }\end{array}$ & & & \\
\hline \multirow{2}{*}{\multicolumn{2}{|c|}{$\overline{\mathrm{pGH}} 10$ or $100 \mu \mathrm{g} / \mathrm{day}$}} & 16 & $2.5 \pm 0.8$ & & \\
\hline & & 16 & & $9.0 \pm 1.8 \quad(5)$ & $\mathrm{s}$ \\
\hline \multicolumn{2}{|c|}{ hGH $8.3 \mu \mathrm{g} /$ day } & $4-5$ & (2) & $5.1 \pm 0.6 \quad(8)$ & $\mathrm{nt}$ \\
\hline \multicolumn{2}{|l|}{$\mathrm{T}_{4} 1 \mu \mathrm{g} /$ day } & $\begin{array}{l}1 \\
4\end{array}$ & $1.2 \pm 0.5$ & $\begin{array}{ll}2.5 \pm 0.8 & (4)^{*} \\
2.0 & (2)\end{array}$ & ns \\
\hline \multicolumn{2}{|c|}{$0.1 \mu \mathrm{g} /$ day } & $13-16$ & $1.2 \pm 0.5$ & $4.3 \pm 2.0 \quad(6)$ & ns \\
\hline \multicolumn{2}{|c|}{$1 \mu \mathrm{g} / \mathrm{day}$} & 13 & $2.3 \pm 1.2$ & & \\
\hline \multicolumn{6}{|c|}{$\mathrm{pGH} 100 \mu \mathrm{g}+0.1 \mu \mathrm{g}$} \\
\hline $\mathrm{T}_{4} /$ day & & 16 & $3.0 \pm 2.4$ & (1) & $\mathrm{nt}$ \\
\hline \multicolumn{6}{|c|}{$\mathrm{hGH} 8.3$ or $25 \mu \mathrm{g}+1 \mu \mathrm{g}$} \\
\hline \multicolumn{2}{|c|}{$\mathrm{T}_{4} /$ day $^{h}$} & 10 & $1.3 \pm 0.4$ & $2.3 \pm 1.2(3)^{*}$ & ns \\
\hline \multicolumn{2}{|c|}{ Insulin 7.5 or $15 \mathrm{mU} /$ day ${ }^{\mathrm{h}}$} & 5 & $1.6 \pm 0.5$ & $3.8 \pm 0.8 \quad(5)^{*}$ & ns \\
\hline \multicolumn{6}{|c|}{ Testosterone } \\
\hline \multicolumn{2}{|c|}{$\begin{array}{l}\delta 20,200 \text { or } 2000 \mu \mathrm{g} / \text { day }^{\mathrm{b}} \\
\text { \& } 20 \text { or } 200 \mu \mathrm{g} / \text { day }^{\mathrm{b}}\end{array}$} & 5 & $2.6 \pm 0.5$ & $4.7 \pm 0.2(10) *$ & s \\
\hline
\end{tabular}

\footnotetext{
a The number of animals is indicated in parentheses; from each animal 2000 cells were analyzed.

${ }^{\mathrm{b}}$ Results of different concentrations were pooled.

* Significantly different from dwarf controls.
}

with 2-3-week-old normals (van Buul-Offers and van den Brande, 1981), the induction of MN in 3-week-old Swiss mice was studied. Table 2 shows the same radiosensitivity for these young mice as for adults, suggesting that the observed differences between dwarf mice and normals cannot be easily attributed to differences in radiosensitivities of various developmental ages at comparable chronological ages.

Treatment of dwarf mice with mitomycin $C$ indicated no induction at all of $M N$, 
TABLE 2

INDUCTION OF MN IN POLYCHROMATIC ERYTHROCYTES AFTER $300 \mathrm{rad}$ X-RAYS OR 2.5 mg MITOMYCIN-C PER kg (DATA POOLED FOR BOTH SEXES; SEX RATIO 1:1)

\begin{tabular}{|c|c|c|c|c|c|}
\hline Mouse strain & Pretreatment & $\begin{array}{l}\text { Treat- } \\
\text { ment }\end{array}$ & $\begin{array}{l}\text { Time } \\
\text { interval } \\
\text { between } \\
\text { treatment } \\
\text { and obser- } \\
\text { vation }(\mathrm{h})\end{array}$ & $\begin{array}{l}\text { Number } \\
\text { of mice }\end{array}$ & $\begin{array}{l}\text { Induced } \\
\mathrm{MN} / 1000 \\
\pm \text { S.E.M. }\end{array}$ \\
\hline$+/+$ (Swiss) & - & MMC & 24 & 6 & $19.7 \pm 3.2$ \\
\hline $\mathrm{dw} / \mathrm{dw}$ (Snell dwarf) & - & $\mathrm{MMC}$ & 24 & 6 & $0 \pm 1.3$ \\
\hline$+/+($ Swiss $)$ & - & $\mathrm{X}$-rays & 18 & 4 & $46.0 \pm 5.3$ \\
\hline$+/+($ Snell $)$ & - & $\mathrm{X}$-rays & 18 & 8 & $39.9 \pm 4.2$ \\
\hline$+/+(\text { Swiss young })^{b}$ & - & $X$-rays & 18 & 4 & $46.5 \pm 5.1$ \\
\hline $\mathrm{dw} / \mathrm{dw}$ (Snell dwarf) & - & $\mathrm{X}$-rays & 18 & 10 & $18.7 \pm 3.3$ \\
\hline$+/+($ Snell $)$ & - & $\mathrm{X}$-rays & 24 & 4 & $8.4 \pm 1.4$ \\
\hline $\mathrm{dw} / \mathrm{dw}$ (Snell dwarf) & - & $\mathrm{X}$-rays & 24 & 2 & 0 \\
\hline $\mathrm{dw} / \mathrm{dw}$ (Snell dwarf) & - & $\mathrm{X}$-rays & 7 & 2 & 0.2 \\
\hline$+/+($ Snell $)$ & $\mathrm{NaCl} 3$ weeks $^{\mathrm{c}}$ & $\mathrm{X}$-rays & 18 & 6 & $35.2 \pm 5.8$ \\
\hline$+/+($ Snell $)$ & $\mathrm{T}_{4}+\mathrm{pGH} 3$ weeks ${ }^{\mathrm{c}}$ & $\mathrm{X}$-rays & 18 & 6 & $40.1 \pm 6.3$ \\
\hline $\mathrm{dw} / \mathrm{dw}$ (Snell dwarf) & $\mathrm{T}_{4}+\mathrm{pGH} 3$ weeks ${ }^{\mathrm{d}}$ & $\mathrm{X}$-rays & 18 & 10 & $34.3 \pm 2.4$ \\
\hline $\mathrm{dw} / \mathrm{dw}$ (Snell dwarf) & $\mathrm{T}_{4}+$ pGH chronically $^{\mathrm{e}}$ & X-rays & 18 & 4 & $30.1 \pm 5.7$ \\
\hline
\end{tabular}

a From each animal, 2000 cells were analyzed.

b Mice were 3 weeks old.

c The mice received subcutaneously $\mathrm{NaCl}$ solution or a cocktail of $0.1 \mu \mathrm{g}$ thyroxine and $0.1 \mathrm{U}$ pGH for 3 weeks 5 days per week, and were subsequently irradiated.

d The mice received subcutaneously a cocktail of $1 \mu \mathrm{g}$ thyroxine and $0.4 \mathrm{U}$ pGH for 3 weeks 5 days per week, and were subsequently irradiated.

- The mice received subcutaneously a cocktail of $1 \mu \mathrm{g}$ thyroxine and $0.1 \mathrm{U}$ pGH for 2 months ( 5 days per week); after 2 additional months without treatment the mice were irradiated.

whereas in Swiss mice significantly enhanced frequencies were observed. The ratio between polychromatic erythrocytes and more mature ones in bone-marrow smears, which normally should be around 1 (Schmid, 1976), was similarly affected in dwarfs and normals $(0.48 \pm 0.07$ vs. $0.40 \pm 0.04)$ and indicated severe cell killing in both genotypes.

After treatment of dwarf mice for 3 weeks with a combination of pGH and thyroxine, at a concentration that stimulated body growth and caused a hyperthyroid status of the animal, the induction of $\mathrm{MN}$ by $300 \mathrm{rad} \mathrm{X}$-rays reached normal values.

Irradiation of dwarf mice treated with pGH and thyroxine, followed by a period of 2 months without treatment, showed an intermediate restoration of normal radiosensitivity (Table 2). Treatment of normal Snell mice with pGH and thyroxine did not change the radiosensitivity for $\mathrm{MN}$ induction in polychromatic erythrocytes (Table 2). 
TABLE 3

THE INDUCTION OF MN IN POLYCHROMATIC ERYTHROCYTES AFTER VARIOUS DOSES OF X-RAYS (DATA POOLED FOR BOTH SEXES; SEX RATIO $1: 1$ )

\begin{tabular}{rlcc}
\hline $\begin{array}{l}\text { Dose } \\
\text { (rad) }\end{array}$ & $\begin{array}{l}\text { Time interval between } \\
\text { irradiation and observation } \\
(\mathrm{h})\end{array}$ & \multicolumn{2}{l}{$\mathrm{MN} / \mathbf{1 0 0 0}$ cells \pm S.E.M. } \\
\cline { 3 - 4 } & & $+/+($ Swiss $)$ & $\mathrm{dw} / \mathrm{dw}$ (Snell dwarf) \\
\hline- & - & $2.0 \pm 0.8$ & $3.8 \pm 1.3$ \\
50 & 18 & $30.0 \pm 2.3$ & $13.8 \pm 2.3$ \\
50 & 27 & $26.8 \pm 1.3$ & $15.0 \pm 0.7$ \\
100 & 18 & $61.8 \pm 8.8$ & $20.0 \pm 2.6$ \\
100 & 27 & $54.0 \pm 5.8$ & $25.0 \pm 3.0$
\end{tabular}

For each point, 4 mice were used, except for unirradiated dwarf mice which consisted of 2 males and 1 female; from each animal 2000 cells were analyzed.

Results of experiments at the lower doses of 50 and 100 rad with two different sampling times are presented in Table 3 . At these lower dose levels, at both sampling times, the induction of $\mathrm{MN}$ in bone-marrow cells of dwarf mice was clearly lower. Although the differences were non-significant, it is interesting to note that, in dwarf mice, the peak yield of $\mathrm{MN}$ was obtained $27 \mathrm{~h}$ after irradiation, but for normal mice at $18 \mathrm{~h}$, suggesting some differences in formation-differentiation kinetics of proerythrocytes. The dose-response relationships for $\mathrm{MN}$ induction in dwarfs and normal mice at $18 \mathrm{~h}$ sampling time are plotted in Fig. 1. For normal mice a maximum was found at around $100 \mathrm{rad}$, whereas in dwarf mice such a distinct peak

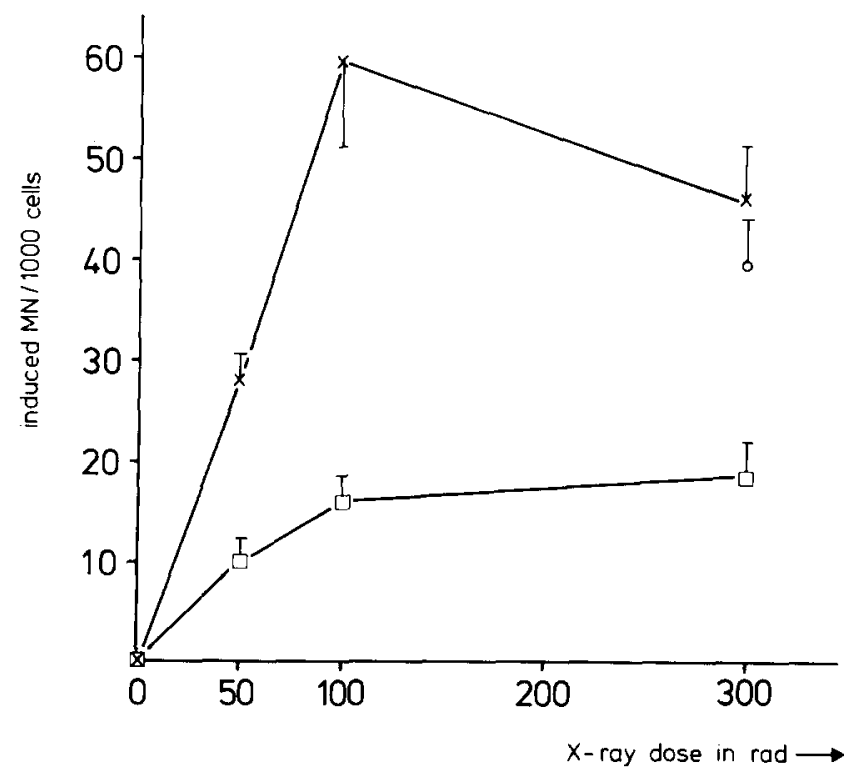

Fig. l. Dose-response relationships for X-ray-induced $\mathrm{MN}$ in bone-marrow cells $18 \mathrm{~h}$ after irradiation. $\times$, Swiss mice; $\square$, Snell dwarf mice; $\bigcirc$, Snell mice. 
seemed to be absent. No change in the ratio between polychromatic erythrocytes and more mature ones was seen in normal or dwarf mice after 50 or $100 \mathrm{rad}$ X-rays, indicating no strong differences in cell killing at these dose levels.

\section{Discussion}

\section{Spontaneous frequencies of $M N$}

In normal and dwarf Snell mice at 10 weeks of age, the spontaneous frequencies of $\mathrm{MN}$ were significantly higher in males than in females, a difference not found at 23 weeks of age and also not in the Swiss random-bred strain possibly owing to their age range of 10-20 weeks. Although Meyne and Legator (1980) reported higher spontaneous frequencies of $\mathrm{MN}$ in male Swiss mice than in females, these differences never reached statistical significance and, in all other cases studied, no differences were found between the sexes (Schmid, 1976; Chrisman and Baumgartner, 1979, 1980; Henry et al., 1980).

\section{Hormone-treated dwarf mice}

Treatment of dwarf mice with growth hormone, thyroxine, insulin and testosterone did not increase the frequencies of $\mathrm{MN}$ present in polychromatic erythrocytes. In contrast, in the male dwarfs a significant decrease of the frequencies of spontaneous $\mathrm{MN}$ was found after treatment with insulin, testosterone and $1 \mu \mathrm{g}$ thyroxine, a dose that caused severe hyperthyroidism, whereas $0.1 \mu \mathrm{g}$ thyroxine, giving a euthyroid status, had an intermediate effect. This is in contrast with the results obtained by others. Judin and Antipenko (1972) found an increase in spontaneous chromosomal aberrations in rat-liver cells after thyroxine therapy. Duca-Marinescu and Negoescu (1973) found an increase in acentric fragments in bone-marrow cells of normal mice after thyroxine treatment, whereas Nilsson et al. (1975) reported an increase of the tendency for satellite-type association in lymphocytes of hyperthyroid patients. Similarly to the situation for thyroxine, Duca-Marinescu and Simionescu (1973) observed an increase for acentric fragments in mouse bone-marrow cells after treatment with growth hormone. These discrepancies between our results and others may be due to the different methods used, and more probably due to the hormonedeficient status of the dwarf mice studied here, whereas other workers used normal animals.

\section{Mutagen-treated mice}

Our results on X-irradiation and mitomycin $\mathrm{C}$ treatment show that dwarf mice are less sensitive to induction of polychromatic erythrocytes than are normal Snell and Swiss mice. As can be expected on theoretical grounds as well as observed by Heddle (1973), Chaubey et al. (1978), Jenssen and Ramel (1978) and Jenssen (1981), the induction pattern of MN by X-rays followed with time is a wave whose shape is determined by factors such as size of dose, sensitivity of target cells, heterogeneity with respect to cell killing, cell-cycle progression and cell differentiation. The results obtained by us at different doses and different fixation times indicate a consistently 
lower induction in dwarf mice suggesting no strong differences in the time sequence of cell differentiation between normal and dwarf mice.

Dose-response studies on $\mathrm{X}$-ray-induced $\mathrm{MN}$ in bone-marrow cells have shown that, in mice, the shape is humped with a maximum around 100 rad (Chaubey et al., 1978). Our observations on Swiss mice are in line with these observations. A humped curve is generally explained in terms of coincidence of the induction of the observed parameter and cell killing in a heterogeneous population. At higher doses, where the cell-killing effect predominates, the aberration-carrying cells are selectively eliminated, resulting in a decrease of the frequencies of aberrations (Russell, 1956; Oftedal, 1968). If a stronger selection against aberration-carrying cells occurs, this will lead to lower yields of aberrations at all doses and a broadening of the peak (Lyon and Cox, 1976; van Buul, 1976 and 1980). Such a feature seems to be present in the dwarf mice. At present, it is not possible to find out whether the increased radiosensitivity with respect to cell killing of dwarf mice is due to an intrinsic situation for all cells or that it results from a difference in cell-cycle kinetics of pro-erythrocytes, leading to different proportions of cells in the various cell-cycle stages with concomitant changes in radiosensitivity. However, the observations on the ratio between the number of polychromatic erythrocytes and more mature ones present in the bone-marrow smears after treatment with $\mathrm{X}$-rays or mitomycin $\mathrm{C}$ suggested no strong differences in cell-killing effect between dwarfs and normal mice.

Another reason for the lower frequencies of mutagen-induced $\mathrm{MN}$ in bone-marrow cells of dwarf mice might be a difference in repair of DNA lesions, but one can only speculate about this. Here it is just interesting to note that dwarf mice also have a lower or retarded tumour induction by several chemical carcinogens (Bielschowsky and Bielschowsky, 1959, 1960 and 1961). Our observation of no increase in MN frequency in dwarf mice after all chronic hormone treatments has to be considered in the light of these lower sensitivities of dwarfs.

The radiation experiments on dwarf mice treated with $\mathrm{pGH}$ plus thyroxine indicate that an increase to normal levels of $\mathrm{MN}$ can be obtained in these animals. This indicates that $\mathrm{pGH}$ plus thyroxine, at the applied concentrations, might influence the cell cycle of dwarf-mouse bone-marrow cells. It has been known for many years that different types and frequencies of chromosomal aberrations are produced by ionizing radiation at different stages of the cell cycle (Evans, 1962; Kihlman, 1977). Thus a change in the cell kinetics of pro-erythrocytes will have an effect on the radiosensitivity with respect to chromosomal aberration production.

Hormonal influence of the cell cycle has been reported by several authors. Bardik (1969) found an effect of growth hormone on the duration of the cell cycle of the oesophageal and jejunal epithelium of hypophysectomized and normal rats, whereas Romanov et al. (1969) and Romanov and Kasavina (1970) claim an increase of the mitotic activity by thyroid-stimulating hormone and thyroxine in the small intestine, bone marrow, cornea and liver of normal rats. When dwarf mice are exposed to $\mathrm{X}$-rays 2 months after termination of hormone treatment, the change in radiosensitivity is still present. This suggests that the presence of the hormones at the moment of irradiation is not essential for the observed effect but that most likely irreversible changes in physiological conditions are involved. A change in the physiological 
condition may very well be accompanied by a change in the metabolism of blood-forming organs by which the length of the cell cycle of mitotically dividing pro-erythrocytes can be influenced. However, the results of Guernsey et al. (1980), showing that the presence of triiodothyronine $\left(T_{3}\right)$ is necessary for neoplastic transformation by $\mathrm{X}$-rays in vitro, indicate that hormones may also directly affect the radiosensitivity.

Judin and Antipenko (1972) reported a significantly lower radiosensitivity with respect to chromosomal aberration production of rat-liver cells after thyroxine treatment. This contrasts with our findings in normal Snell mice, where no change in the frequencies of radiation-induced $\mathrm{MN}$ was found, although these mice were treated with lower doses than the dwarfs as a result of which no increase of thyroxine level in blood was observed.

In general, it can be concluded that, in the hypopituitary dwarf mouse, growth hormone, thyroxine, insulin and testosterone do not act as mutagenic agents as judged by the $\mathrm{MN}$ test. The induction of $\mathrm{MN}$ in dwarf mice by $\mathrm{X}$-rays is lower and follows a drastically different dose-effect relationship compared with that in normal mice. The lower radiosensitivity of dwarf mice can be reconstructed to normal levels by treatment with a combination of growth hormone and thyroxine, an effect that persists until at least 2 months after treatment. To interpret the mechanisms behind the induction of $\mathrm{MN}$ by various treatments, it is essential to gain more information on the course of events in the formation of $\mathrm{MN}$ in relation to different stages of the cell cycle, which can be blocked or retarded in dwarf mice.

\section{Acknowledgements}

We thank Mr. H.J. Goudzwaard and P. van den Klundert for their technical assistance.

The work was supported by the Association of Euratom and the University of Leiden, contract no. 195-76-1 BIO N, the International Atomic Energy Agency, contract no. 1745/R4/RB, the Health Research Organization TNO and the Dutch Foundation for Medical Research (FUNGO), grant no. 13-24-12.

\section{References}

Bardik, Yu. V. (1969) Effect of somatotropic hormone on duration of DNA synthesis during the mitotic cycle, Bull. Exp. Biol. Med. (U.S.S.R.), 68, 930-932.

Bielschowsky, F., and M. Bielschowsky (1959) Carcinogenesis in the pituitary dwarf mouse, The response to methylcholanthrene injected subcutaneously, Br. J. Cancer, 13, 302-305.

Bielschowsky, F., and M. Bielschowsky (1960) Carcinogenesis in the pituitary dwarf mouse, The response to 2-aminofluorene, Br. J. Cancer, 14, 195-199.

Bielschowsky, F., and M. Bielschowsky (1961) Carcinogenesis in the pituitary dwarf mouse, The response to dimethylbenzanthracene applied to the skin, Br. J. Cancer, 15, 257-262.

Bishun, N., N. Smith, D. Williams and J. Mills (1976) Cytological effects of the oral contraceptive, Mutation Res., 39, 97-110.

Buul, P.P.W. van (1976) A correlative study on the frequencies of radiation-induced chromosome aberrations in somatic and germ cells of mammals, Thesis, University of Leiden. 
Buul, P.P.W. van (1980) Dose-response relationship for X-ray-induced reciprocal translocations in stem cell spermatogonia of the rhesus monkey (Macaca mulatta), Mutation Res., 73, 363-375.

Buul-Offers, S. van, and J.L. van den Brande (1978) The Snell dwarf mouse, I. General growth pattern. before and during growth hormone and thyroxine therapy, Acta Endocrinol., 89, 632-645.

Buul-Offers, S. van, and J.L. van den Brande (1979) Effect of growth hormone and peptide fractions containing somatomedin activity on growth and cartilage metabolism of Snell dwarf mice, Acta Endocrinol., 92, 242-257.

Buul-Offers, S. van, and J.L. van den Brande (1981) The growth of different organs of normal and dwarfed Snell mice before and during growth hormone therapy, Acta Endocrinol., 96, 46-58.

Chaubey, R.C., K.P. George and K. Sundaram (1978) X-ray-induced micronuclei in the bone marrow erythrocytes of mice. Int. J. Biol., 33, 507-510.

Chrisman, C.L., and A.P. Baumgartner (1979) Cytogenetic effects of diethylstilbestrol-diphosphate (DBS-dp) on mouse bone marrow monitored by the micronucleus test, Mutation Res., 67, 157-160.

Chrisman, C.L., and A.P. Baumgartner (1980) Micronuclei in bone marrow cells of mice subjected to hyperthermia, Mutation Res., 77, 95-97.

Duca-Marinescu, D., and J. Negoescu (1973) The mutagenic effect of thyroxin, Rev. Roum. Endocrinol., $10,149-152$.

Duca-Marinescu, D., and L. Simionescu (1973) The cytogenetic effects of the somatotropic hormone, Rev. Roum. Endocrinol., 10, 311-316.

Elbling, L. (1975) Malformation induced by hormones in mice and their transmission to the offspring, Exp. Path. Biol., 11, 115-122.

Evans, H.J. (1962) Chromosome aberrations induced by ionizing radiations, Int. Rev. Cytol., 13, 221-321.

Guernsey, D.L., A. Ong and C. Borek (1980) Thyroid hormone modulation of X-ray-induced in vitro neoplastic transformation, Nature (London), 288, 591-592.

Heddle, J.A. (1973) A rapid in vivo test for chromosomal damage, Mutation Res., 18, 187-190.

Henry, M., S. Lupo and K.T. Szabo (1980) Sex difference in sensitivity to the cytogenetic effects of ethyl methanesulfonate in mice demonstrated by the micronucleus test, Mutation Res., 69, 385-387.

Jenssen, D. (1981) Low-dose mutagenicity in mammalian cells. Thesis University of Stockholm.

Jenssen, D., and C. Ramel (1978) Factors affecting the induction of micronuclei at low doses of X-rays, MMS and dimethylnitrosamine in mouse erythroblasts, Mutation Res., 58, 51-65.

Judin, G.I., and E.N. Antipenko (1972) Post-irradiation restoration of somatic cell chromosomes in mammals, The influence of thyroxine on the frequency of chromosome aberrations in liver cells of rats, Int. J. Radiation Biol., 22, 501-506.

Kihlman, B.A. (1977) Caffeine and Chromosomes, Elsevier, Amsterdam.

Lederbur, M. von, and W. Schmid (1973) The micronucleus test, Methodological aspects, Mutation Res., $19,109-117$.

Lyon, M.F., and D.B. Cox (1975) The induction by X-rays of chromosome aberrations in male guinea pigs, rabbits and golden hamsters, III. Dose-response relationship after single doses of X-rays to spermatogonia, Mutation Res., 29, 407-422.

Meyne, J., and M.S. Legator (1980) Sex-related differences in cytogenetic effects of benzene in the bone marrow of Swiss mice, Environ. Mutagen., 2, 43-50.

Nilsson, C., A. Hansson and G. Nilsson (1975) Influence of thyroid hormones on satellite association in man and the origin of chromosome abnormalities, Hereditas, 80, 157-166.

Oftedal, P. (1968) A theoretical study of mutant yield and cell killing after treatment of heterogeneous cell populations, Hereditas, $60,177-210$.

Romanov, Yu.A., and B.S. Kasavina (1970) Effect of thyrotropic hormone on cell division in vivo, Bull. Exp. Biol. Med. (U.S.S.R.), 70, 1055-1057.

Romanov, Yu.A., B.S. Kasavina, V.I. Prilutski, A.N. Blokhina, V.P. Rybakov and N.M. Suvorova (1969) Action of thyroxine on cell division in vivo, Bull. Exp. Biol. Med. (U.S.S.R.), 67, 548-549.

Russell, W.L. (1956) Lack of linearity between mutation rate and dose for X-ray-induced mutations in mice, Genetics, 41, 658-659.

Schmid, W. (1976) The micronucleus test for cytogenetic analysis, in: A. Hollaender (Ed.), Chemical Mutagens: Principles and Methods for their Detection, Plenum, New York, Vol. 4, pp. 31-52.

Snell, G.D. (1929) Dwarf, a new mendelian recessive character of the house mouse, Proc. Natl. Acad. Sci. (U.S.A.), 15, 733-734. 